\title{
Relationship of Potential Inflammatory Markers Namely Neutrophile Lymphocyte Ratio and Platelet Lymphocyte Ratio With the Severity of Obstructive Sleep Apnea
}

\author{
Oğuz DİKBAŞ ${ }^{1}$, Nilgün ERTEN ${ }^{2}$, Fatma KÜÇÜKER ${ }^{3}$, Özge YILMAZ AKŞEHİRLİ ${ }^{4}$ \\ ${ }^{1}$ Giresun University Faculty of Medicine, Department of Internal Medicine, Giresun, Turkey \\ ${ }^{2}$ Ordu State Hospital, Department of Neurology, Ordu, Turkey \\ ${ }^{3}$ Ordu State Hospital, Chest Diseases Department, Ordu, Turkey \\ ${ }^{4}$ Duzce University School of Medicine, Department of Biostatistics, Duzce, Turkey
}

\begin{abstract}
Aim: The aim of the present study is to evaluate hematological parameters in patients with obstructive sleep apnea syndrome (OSAS). Material and Methods: Patients underwent a polysomnographic (PSG) test at our sleep laboratory was retrospectively reviewed. Patients with cancer, cardiovascular disease, hematologic disorders, infectious diseases and rheumatologically disorders, renal or hepatic insufficiency were excluded from the study. Two hundred and ten OSAS patients with an apnea-hypopnea index (AHI) of more than five events and 57 controls with an AHI of less than four events were included. Study population was divided into four groups depending on the AHI as: mild OSAS (AHI= 5-15), moderate OSAS (AHI=15-30), severe OSAS (AHI $>30)$, and the control $(\mathrm{AHI}<5)$. Hematologic parameters were measured and compared.

Results: Platelet lymphocyte ratio was significantly lower in patients with OSAS compared to the control $(p=0.050)$. Neutrophil lymphocyte ratio between OSAS and the control was not different $(p=0.947)$. Serum triglyceride level and mean platelet volume were significantly higher in patients with OSAS $(p<0.0001 ; p=0.043)$. Platelet distribution width was significantly higher in severe OSAS group compared to control, mild and moderate OSAS subgroups (0.014).

Conclusion: No relationship was found between OSAS and NLR. There is a debate over putative relationship between NLR, PLR, and OSAS.

Key Words: Obstructive sleep apnea syndrome, OSAS, Neutrophil lymphocyte ratio, Platelet lymphocyte ratio

\section{Enflamatuar Belirteç Olarak Nötrofil Lenfosit Oranı, Platelet Lenfosit Oranı gibi Hematolojik Parametrelerin Tıkayıcı Uyku Apne Sendromunun Şiddeti ile İlişkisinin Değerlendirilmesi}

\section{ÖZET}

Amaç: Bu çalışmanın amacı tıkayıcı uyku apnesi (OSAS) olan hastalarda hematolojik parametrelerin değerlendirilmesidir.

Gereç ve Yöntemler: Bu araştırmada uyku laboratuvarında Polisomnografi testi yapılan hastalar geriye dönük olarak değerlendirilmiştir. Kanser, kardiyovasküler hastalık, hematolojik bozukluk, enfeksiyon hastalıkları, romatolojik hastalıklar, renal ve hepatik yetmezlik olan hastalar çalışmaya alınmamıştır. Çalışmaya apne-hipopne endeksi 5 olaydan fazla olan 210 hasta ve 57 AHI 5 den az olan kontrol olarak alınmıştır. Araştırma grubu polisomnografideki AHI skorlarına göre 4 gruba ayrılmıştır: hafif OSAS (AHI= 5-15), orta OSAS (AHI=15$30)$, ciddi OSAS (AHI> 30), ve kontrol $(\mathrm{AHI}<5)$. Hematolojik parametreler değerlendirilmiş ve karşılaştırılmıştır.

Bulgular: Trombosit lenfosit oranı OSAS hastalarında kontrol grubuna göre anlamlı düşük saptanmıştır. $(p=0.050)$. OSAS ve kontrol grupları arasında nötrofil lenfosit oranı yönünden istatistiksel olarak anlamlı farklılık izlenmemiştir $(p=0.947)$. Serum trigliserid ve ortalama trombosit hacmi OSAS hastalarında anlamlı yüksek izlenmiștir $(p<0.0001 ; p=0.043)$. Trombosit dağılım hacmi ciddi OSAS grubunda kontrol grubuna ve diğer OSAS alt gruplarına göre anlamlı yüksek saptanmıştır. $(p=0.014)$.

Sonuç: OSAS ve NLR arasında herhangi bir ilişki izlenmemiştir. NLR, PLR, ve OSAS arasındaki olası ilişki üzerine hâlâ araştırmaların sonuçları tartışmalıdır.

Anahtar Sözcükler: Tıkayıcı uyku apne sendromu, OSAS, Nötrofil lenfosit oranı, Platelet lenfosit oranı

DOI: $10.25048 /$ tjdo.2017.20 


\section{INTRODUCTION}

Obstructive sleep apnea syndrome (OSAS), characterized by recurrent obstruction of the airway during sleep has negative impact on the health of millions of people around the world. This syndrome is characterized by episodic hypoxemia, oxidative stress, and sleep disorders at night. The prevalence is $4 \%$ in males and around $2 \%$ in females, respectively (1). OSAS is the most prevalent sleep disorder and ranks as the second most prevalent respiratory disorder following asthma (1-3). There is a 2- to 3-fold increase in the incidence and severity of OSAS with age $(4,5)$. OSAS is known to cause neurologic, metabolic, and cardiovascular disturbances (611). This syndrome has an important place in the practice of preventive medicine due to high risk of morbidity and mortality and the treatable nature of it $(12,13)$.

Complete blood count is a cheap, practical, and easyto-perform test. Parameters such as red cell distribution width (RDW), mean platelet volume (MPV), neutrophil lymphocyte ratio (NLR), and platelet lymphocyte ratio (PLR) can be easily obtained with routine blood count. MPV is a laboratory parameter providing information about platelet functions in the state of thrombosis, and this parameter has therefore been suggested as a marker of hemostasis (14, 15) NLR is currently considered as a parameter indicating both elevation of neutrophils reflecting acute inflammation and decreased lymphocytes reflecting physiological stress. Thus, this parameter has been suggested as a new prognostic marker (16-18). Azab et al. studied changes in PLR in long term follow up as the marker of mortality in patients with sustained non-ST segment elevation myocardial infarction (NSTEMI). It was indicated that elevated PLR was an independent predictor of mortality in the long-term follow up of NSTEMI (19).

The objective of the present study was to examine the changes in PLR and other hematologic parameters in patients with OSAS. The other aim of this study is to evaluate the relationship between severity of OSAS and PLR.

\section{MATERIAL and METHODS}

\section{Subjects}

Subjects who have been admitted to our hospital for polysomnography test (PSG) between November 2012 and December 2014 were evaluated retrospectively. Patients who have been diagnosed cardiovascular disease according to clinical history, physical examination and EKG were excluded from the study. Subjects who have been taking antibiotics and anti-inflammatory drugs (NSAIDs ets.), with known cardiovascular disease, hematologic disorders, cancer, renal and hepatic failure, infectious disease, and rheumatologic disorders were excluded. This study was approved by local ethic committee.

\section{Biochemical Analysis}

Venous blood samples were taken into Becton Dickinson Vacutainer tube following 12 hours fast. Glucose, total cholesterol, triglycerides, high density lipoprotein (HDL), low density lipoprotein (LDL) measurements were made with calorimetric methods (Abott Laboratories; Illinois (USA). Whole blood count were evaluated with automatic measurement device (Abbott Cell-Dyne Ruby; IL 60064 USA).

PSG test was performed with Compumedics E series 44 channel PSG device. The PSG recordings included electrocardiography, chest excursions, electroencephalography, pulse oximetry and leg electromyography. The apnea-hypopnea index (AHI) was defined as the average number of apnea and hypopnoea per hour of sleep. Data's were scored manually. Patients were separated into the four groups in according to polisomnographic AHI scores. Groups were determined as; Apnoea Hypopnoea index (AHI) score between, 5-15, 1530 , more than $30(\mathrm{AHI}>30)$ and $0-5(\mathrm{AHI}<5)$. Patients with AHI $<5$ were accepted as control. AHI scores 5-15, 15-30, more than 30 were accepted as mild, moderate and severe OSAS respectively.

\section{Statistical Analysis}

Student $t$ test and Mann Whitney $U$ test were used for comparison of numeric parameters between groups either normally or not normally distributed. Comparison of OSAS subgroups according to severity were made with Analysis of Variance (ANOVA) for normally distributed parameters or Kruskal Wallis test for not normally distributed parameters accordingly and multiple comparison test of Bonferroni were used for evaluation of the difference. Chi square test were used for evaluation of categorical variables. Pearson correlation analysis for normally distributed variables or Spearman's correlation analyses for not normally distributed variables were used to evaluate the relation between numeric variables. A model with multiple regression analysis was used for determining parameters affecting the severity of OSAS. All the data analyses were performed using the Statistical Package for Social Sciences SPSS (PASW ver.18). $\mathrm{P}<0.05$ probability value was considered as significant.

\section{RESULTS}

Mean age and BMI of OSAS group were found to be higher than control (Table 1). There were statistically significant difference between groups in terms of TG, and PLR $(\mathrm{p}<0.0001, \mathrm{p}=0.050$, respectively) (Table 1$)$. AHI, body mass index, glucose, WBC, and MPV values were also statistically different between groups $(\mathrm{p}<0.0001, \mathrm{p}<0.0001, \mathrm{p}=0.013$, $\mathrm{p}=0.029$, and $\mathrm{p}=0.043$, respectively) (Table 1 ; Table 2 ). Patients were grouped according to the OSAS severity as 
mild, moderate and severe: Statistically significant difference were found between groups in terms of age, AHI, BMI, TG, WBC, and MPV ( $p=0.003, p<0.0001, p<0.0001, p=0.005$, $\mathrm{p}=0.050$, and $\mathrm{p}<0.0001$, respectively) (Table 3 ). The mean TG serum level was lower in control compared to moderate and severe OSAS group ( $\mathrm{p}=0.028$ and 0.003 , respectively). The mean WBC count was higher in patients with severe OSAS compared to control $(\mathrm{p}=0.041)$. The mean MPV was lower in patients with severe OSAS compared to mild and moderate OSAS ( $\mathrm{p}=0.001$ ), and the mean MPV was higher in patients with moderate and mild OSAS compared to control $(\mathrm{p}=$ $0.024)$. There were significant differences between OSAS and control groups in terms of glucose and PDW ( $\mathrm{p}=0.003$ and $\mathrm{p}=0.014$ ) (Table 3 ). The mean PDW was higher in patients with severe OSAS compared to patients with mild OSAS $(\mathrm{p}=0.003)$. No significant difference was observed between OSAS and control in terms of DM, HT, and smoking status $(p>0.05)$.

There was a weak positive correlation between HDL and RDW ( $r=0.173, p=0.012)$, AHI and PLT $(r=0.137$, $\mathrm{p}=0.047)$, AHI and PDW $(\mathrm{r}=0.249, \mathrm{p}<0.0001)$, BMI and $\mathrm{WBC}(\mathrm{r}=0.143, \mathrm{p}=0.038)$, BMI and RDW $(\mathrm{r}=0.229$, $\mathrm{p}=0.001)$, total cholesterol and PLR $(\mathrm{r}=0.159, \mathrm{p}=0.022)$, total cholesterol and PLT $(r=0.230, p=0.001)$, LDL and PLR $(\mathrm{r}=0.150, \mathrm{p}=0.031)$, and LDL and PLT $(\mathrm{r}=0.216, \mathrm{p}=0.002)$, serum glucose and RDW ( $\mathrm{r}=0.136, \mathrm{p}=0.049)$. There was a weak negative correlation between LDL and MPV ( $\mathrm{r}=$ $-0.159, p=0.022)$, HDL and WBC $(r=-0.209, p=0.002)$, AHI and MPV $(r=-0.224, p=0.001)$ (Table 4).

Table 1: Demographic Features

\begin{tabular}{lccc}
\hline \multicolumn{1}{c}{ Characteristics } & Subjects with OSAS & Control & p Value \\
\hline Age (Year \pm SD) & $51.06 \pm 10.38$ & $47.77 \pm 12.74$ & $\mathbf{0 . 0 4 5}$ \\
\hline Gender (Male/Female) & $110 / 100$ & $25 / 32$ & 0.254 \\
\hline Smoking (Present/Absent) & $22 / 188$ & $9 / 47$ & 0.246 \\
\hline Hypertension (Present/Absent) & $94 / 116$ & $18 / 39$ & 0.740 \\
\hline Diabetes mellitus (Present/Absent) & $59 / 151$ & $9 / 48$ & 0.060 \\
\hline BMI (kg/m2 minimum-maximum) & $33.00(29.00-36.00)$ & $29.00(26.00-32.00)$ & $<\mathbf{0 . 0 0 0 1}$ \\
\hline
\end{tabular}

Parameters with normal distribution were presented as mean \pm SD. Parameters without normal distribution was presented as median $(25$ percentile 75 percentile)

Table 2: Laboratory parameters and clinical features.

\begin{tabular}{lccc}
\hline \multicolumn{1}{c}{ Parameters } & Subjects with OSAS & Control & p Value \\
\hline Total cholesterol(mg/dl \pm SD) & $165.51 \pm 80.69$ & $127.26 \pm 67.75$ & $<\mathbf{0 . 0 0 0 1}$ \\
\hline LDL(mg/dl \pm SD) & $199.04 \pm 35.81$ & $200.64 \pm 38.74$ & 0.768 \\
\hline HDL(mg/dl \pm SD) & $122.49 \pm 31.79$ & $127.98 \pm 31.57$ & 0.252 \\
\hline PLR(ratio, minimum-maximum) & $44.82 \pm 10.35$ & $46.38 \pm 12.85$ & 0.339 \\
\hline Platelet (PLT/mm3 \pm SD) & $109.95 \pm 35.03$ & $121.21 \pm 51.49$ & $\mathbf{0 . 0 5 0}$ \\
\hline AHI (minimum-maximum) & $251.53 \pm 65.12$ & $251.22 \pm 52.59$ & 0.974 \\
\hline Glucose(mg/dl \pm SD) & $20.90(11.90-44.90)$ & $3.20(1.80-4.00)$ & $<\mathbf{0 . 0 0 0 1}$ \\
\hline WBC/mm3 (minimum-maximum) & $98.00(90.00-112.00)$ & $92.00(88.00-100.00)$ & $\mathbf{0 . 0 1 3}$ \\
\hline NLR (ratio, minimum-maximum) & $7.12(6.22-8.52)$ & $6.73(5.66-7.59)$ & $\mathbf{0 . 0 2 9}$ \\
\hline PDW (minimum-maximum) & $1.72(1.33-2.21)$ & $1.67(1.40-2.13)$ & 0.947 \\
\hline MPV (minimum-maximum) & $13.80(11.60-19.30)$ & $14.40(11.90-19.70)$ & 0.345 \\
\hline RDW (minimum-maximum) & $10.10(9.10-10.90)$ & $9.80(8.10-10.50)$ & $\mathbf{0 . 0 4 3}$ \\
\hline
\end{tabular}

Parameters with normal distribution were presented as mean \pm SD. Parameters without normal distribution was presented as median $(25$ percentile -75 percentile)

PLR: Platelet lymphocyte ratio, AHI: Apnea hyperpnoea index, WBC: White blood cell, NLR: Neutrophile lymphocyte ratio, PDW: Platelet distribution width, MPV: Mean platelet volume, RDW: Red cell distribution width. 
Table 3: The comparison of clinical and laboratory parameters according to the severity of OSAS.

\begin{tabular}{|c|c|c|c|c|c|}
\hline \multirow[t]{2}{*}{ Parameters } & $\begin{array}{l}\text { Mild OSAS } \\
\text { (AHI 5-15) }\end{array}$ & $\begin{array}{l}\text { Moderate OSAS } \\
\text { (AHI 15-30) }\end{array}$ & $\begin{array}{c}\text { Severe OSAS } \\
(\text { AHI > 30) }\end{array}$ & Control $(\mathrm{AHI}<5)$ & \multirow[t]{2}{*}{$P$ value } \\
\hline & Mean \pm S.D. & Mean \pm S.D. & Mean \pm S.D. & Mean \pm S.D. & \\
\hline Age (year) & $48.15 \pm 9.76$ & $51.04 \pm 9.15$ & $53.98 \pm 11.40$ & $47.77 \pm 12.74$ & 0.003 \\
\hline AHI & $9.57 \pm 2.67$ & $21.51 \pm 3.98$ & $64.09 \pm 24.23$ & $2.86 \pm 1.40$ & $<0.0001$ \\
\hline BMI (kg/m2) & $31.84 \pm 5.37$ & $33.22 \pm 5.67$ & $35.62 \pm 6.70$ & $29.10 \pm 4.78$ & $<0.0001$ \\
\hline Triglycerides (mg/dl) & $154.58 \pm 74.36$ & $166.29 \pm 84.88$ & $175.65 \pm 82.23$ & $127.26 \pm 67.75$ & 0.005 \\
\hline Total Cholesterol (mg/dl) & $199.97 \pm 35.57$ & $193.30 \pm 31.88$ & $203.85 \pm 39.31$ & $200.64 \pm 38.74$ & 0.378 \\
\hline LDL (mg/dl) & $121.80 \pm 30.01$ & $117.29 \pm 31.20$ & $128.40 \pm 33.57$ & $127.98 \pm 31.57$ & 0.137 \\
\hline $\mathrm{HDL}(\mathrm{mg} / \mathrm{dl})$ & $46.92 \pm 10.90$ & $45.18 \pm 10.66$ & $42.35 \pm 9.03$ & $46.38 \pm 12.85$ & 0.067 \\
\hline Glucose (mg/dl) & $\begin{array}{c}94.50 \\
(89.0-106.00) \\
\end{array}$ & $\begin{array}{c}96.00 \\
(92.00-108.00) \\
\end{array}$ & $\begin{array}{c}103.00 \\
(92.00-125.00) \\
\end{array}$ & $\begin{array}{c}92.00 \\
(88.00-100.00) \\
\end{array}$ & 0.003 \\
\hline WBC & $7.39 \pm 2.08$ & $7.24 \pm 1.59$ & $7.89 \pm 2.05$ & $6.96 \pm 2.05$ & 0.050 \\
\hline NLR & $1.64(1.17-2.21)$ & $1.66(1.25-2.16)$ & $1.81(1.46-2.26)$ & $1.67(1.40-2.13)$ & 0.390 \\
\hline RDW & $13.15(12.5-13.90)$ & $13.35(12.60-13.90)$ & $13.10(12.10-13.90)$ & $13.10(12.20-13.50)$ & 0.554 \\
\hline Platelet & $243.14 \pm 62.06$ & $249.07 \pm 59.42$ & $262.38 \pm 72.56$ & $251.22 \pm 52.59$ & 0.325 \\
\hline MPV & $10.16 \pm 1.21$ & $10.16 \pm 1.39$ & $9.07 \pm 2.04$ & $9.33 \pm 1.81$ & $<0.0001$ \\
\hline PDW & $13.50(11.4-15.30)$ & $13.70(11.50-19.00)$ & $16.70(12.20-19.80)$ & $14.40(11.90-19.70)$ & 0.014 \\
\hline PLR & $106.56 \pm 38.26$ & $110.95 \pm 35.40$ & $112.33 \pm 31.33$ & $121.21 \pm 51.49$ & 0.212 \\
\hline
\end{tabular}

Parameters with normal distribution were presented as mean \pm SD. Parameters without normal distribution was presented as median $(25$ percentile - 75 percentile)

BMI: Body mass index, PLR: Platelet lymphocyte ratio, AHI: Apnea hyperpnoea index, WBC: White blood cell, NLR: Neutrophile lymphocyte ratio, PDW: Platelet distribution width, MPV: Mean platelet volume, RDW: Red cell distribution width.

Table 4: Correlation analysis between parameters.

\begin{tabular}{lllllllll}
\hline Parameters & \multicolumn{7}{c}{ Subjects with OSAS } \\
\hline \multirow{2}{*}{ AHI } & & WBC & NLR & PLR & Platelet & PDW & MPV & RDW \\
\hline \multirow{2}{*}{ BMI (kg/m2) } & r value & 0.117 & 0.066 & 0.111 & 0.137 & 0.249 & -0.224 & -0.056 \\
\cline { 2 - 9 } & p value & 0.092 & 0.345 & 0.110 & $\mathbf{0 . 0 4 7}$ & $<\mathbf{0 . 0 0 0 1}$ & $\mathbf{0 . 0 0 1}$ & 0.421 \\
\hline \multirow{2}{*}{ Triglicerides (mg/dl) } & r value & 0.143 & 0.040 & 0.030 & 0.080 & 0.079 & 0.033 & 0.229 \\
\cline { 2 - 9 } & p value & $\mathbf{0 . 0 3 8}$ & 0.568 & 0.669 & 0.246 & 0.254 & 0.634 & $\mathbf{0 . 0 0 1}$ \\
\hline \multirow{2}{*}{ Total Cholesterol (mg/dl) $)$} & r value & 0.025 & -0.128 & -0.045 & 0.092 & -0.083 & -0.048 & 0.014 \\
\cline { 2 - 9 } & p value & 0.718 & 0.066 & 0.519 & 0.185 & 0.230 & 0.493 & 0.843 \\
\hline \multirow{2}{*}{ LDL(mg/dl) } & p value & -0.063 & -0.132 & 0.159 & 0.230 & 0.008 & -0.116 & 0.095 \\
\hline \multirow{2}{*}{ HDL(mg/dl) } & r value & 0.022 & -0.029 & 0.150 & 0.216 & 0.097 & -0.159 & 0.050 \\
\cline { 2 - 9 } & p value & 0.752 & 0.679 & $\mathbf{0 . 0 3 1}$ & $\mathbf{0 . 0 0 2}$ & 0.167 & $\mathbf{0 . 0 2 2}$ & 0.475 \\
\hline \multirow{2}{*}{ Glucose(mg/dl) } & r value & -0.209 & -0.127 & 0.054 & 0.000 & -0.050 & 0.084 & 0.173 \\
\cline { 2 - 9 } & p value & $\mathbf{0 . 0 0 2}$ & 0.067 & 0.436 & 0.996 & 0.470 & 0.223 & $\mathbf{0 . 0 1 2}$ \\
\hline & r value & 0.049 & -0.069 & -0.084 & -0.009 & 0.127 & 0.033 & 0.136 \\
\cline { 2 - 9 }$y$ & p value & 0.479 & 0.317 & 0.228 & 0.895 & 0.066 & 0.636 & $\mathbf{0 . 0 4 9}$ \\
\hline
\end{tabular}

Pearson correlation analysis was performed.

BMI: Body mass index, PLR: Platelet lymphocyte ratio, WBC: White blood cell, NLR: Neutrophile lymphocyte ratio, PDW: Platelet distribution width, MPV: Mean platelet volume, RDW: Red cell distribution width. 


\section{DISCUSSION}

The present study investigated hematologic parameters in patients with OSAS and their relationship with disease severity and metabolic markers. Accordingly, there was a negative correlation between AHI and MPV and a linear relationship between AHI and PDW. There was also a significant difference in terms of MPV between OSAS and the control groups. NLR, PDW, and RDW parameters were not significantly different in the two groups.

Platelets play an important role in progression of atherosclerosis. An elevated platelet number compared to lymphocyte may result in vascular events (20). In a study performed by Gary $\mathrm{T}$ et al. showed that increase in inflammatory markers like CRP correlated with PLR (20). That is why PLR cheap and easy way to be a potential marker for prediction atherosclerotic lesions like coronary artery disease. Koseoglu et al., found that, PLR was significantly higher in patients with OSAS compared to the control group (21). There was also a strong correlation between PLR and OSAS (21). The authors suggested that PLR could be a strong biomarker in patients with OSAS (21). However, in the present study, PLR was significantly lower in patients with OSAS compared to the control group.

Yenigun A et al evaluated the relationship between OSAS and NLR and found a positive correlation between NLR and AHI in patients with OSAS (22). In another study done in patients with metabolic syndrome showed increased NLR (23). In the present study, NLR did not significantly different between patients with OSAS and the control group. Also we have not found any correlation between NLR and OSAS severity. However, based on the findings of the current study and other studies in the literature, it is too early to suggest that NLR could be used as a marker in evaluating severity of OSAS. Further studies are required in this regard.

Another interesting finding of our study is elevation in WBC count in OSAS. WBC count is also different in between OSAS subgroups. Christoffersson $\mathrm{G}$ et al revealed increased neutrophile count in acutely sleep deprived healthy young men (24). Boudjeltia KZ et al. demonstrated that: Sleep restriction resulted in increase in WBC (25). The increased WBC in OSAS patients may be related with higher adrenalin and cortisol levels in sleep deprived patients (25). Also, leukocytes have an oxidative damage on the vascular bed (25). These all may be the potential link between cardiovascular disease and OSAS.

There are controversial data regarding the changes in lipid profile of patients with OSAS $(26,27)$. One study reported significantly higher TG values in patients with OSAS (28). Chou et al. reported that hypertriglyceridemia was more frequently observed in patients with OSAS (29). In a study conducted at the Mayo clinic, the frequency of hyperlipidemia was similar (30). Li et al. showed that chronic intermittent hypoxia stimulated synthesis of triglycerides (31). The present study was consistent with the literature; found significantly higher TG values in patients with OSAS.

OSAS is known to pose a risk for cardiovascular and cerebrovascular disorders (7, 9-11). The pathophysiological basis of this relationship still remains unclear. Increased MPV values indicate platelet activation. Large platelets possess high thrombotic potential. MPV is higher in OSAS and remarkable increase with increasing severity of OSAS $(32,33)$. Contrary to this opinion, some suggest that platelet markers do not directly indicate platelet activation (34). In the present study, subgroup analysis according to the severity of OSAS showed statistically significant differences in terms of MPV. The interesting finding of our data is decrease in MPV values of the patients with severe OSAS compared to mild and moderate OSAS groups. Gunbatar et al. also reported similar findings in their study (32). It is early for the use of MPV in determining the severity of OSAS and further studies are required in this regard. A negative correlation was also observed between MPV and AHI. Hypoxia, sympathetic over-activation, and chronic inflammation are among the possible mechanisms underlying platelet activation in OSAS.

Another finding of the current study was a linear relationship between AHI and PDW. The study by Kurt et al. reported a positive correlation between PDW and AHI (35). Vagdatli et al. suggested that PDW was a superior marker in determining the severity of OSAS compared to MPV (36). Similar to our findings, PDW could be a useful and easy-to-measure parameter in determining the severity of OSAS.

The limitations of the present study are age difference between groups andabsence of inflammatory markers such as CRP, interleukin and tumor necrosis factor alpha. The lack of testing for endothelial dysfunction is another limitation.

In conclusion, MPV was significantly higher in patients with OSAS; however, the significance of this relationship did not correlate with the severity of OSAS. This finding is consistent with the literature and further studies are required. The correlation between PDW and AHI is another finding of the present study, and PDW might be a promising marker in determining the severity of OSAS. On the other hand, no relationship was found between OSAS and LNR. There is a debate over putative relationship between NLR, PLR and OSAS. Further studies are required on a larger number of patients for this issue. 


\section{REFERENCES}

1. Gharibeh T, Mehra R. Obstructive sleep apnea syndrome: natural history, diagnosis, and emerging treatment options. Nature and science of sleep. 2010;2:233-55.

2. Azagra-Calero E, Espinar-Escalona E, Barrera-Mora JM, Llamas-Carreras JM, Solano-Reina E. Obstructive sleep apnea syndrome (OSAS). Review of the literature. Medicina oral, patologia oral y cirugia bucal. 2012;17(6):e925-9.

3. Maspero C, Giannini L, Galbiati G, Rosso G, Farronato G. Obstructive sleep apnea syndrome: a literature review. Minerva stomatologica. 2015;64(2):97-109.

4. Munoz R, Duran-Cantolla J, Martinez-Vila E, Gallego J, Rubio $\mathrm{R}$, Aizpuru F, et al. Severe sleep apnea and risk of ischemic stroke in the elderly. Stroke; a journal of cerebral circulation. 2006;37(9):2317-21.

5. Partinen M. Epidemiology of obstructive sleep apnea syndrome. Current opinion in pulmonary medicine. 1995;1(6):482-7.

6. Botros N, Concato J, Mohsenin V, Selim B, Doctor K, Yaggi HK. Obstructive sleep apnea as a risk factor for type 2 diabetes. The American journal of medicine. 2009;122(12):1122-7.

7. Chen L, Pei JH, Chen HM. Effects of continuous positive airway pressure treatment on glycaemic control and insulin sensitivity in patients with obstructive sleep apnoea and type 2 diabetes: a meta-analysis. Archives of medical science : AMS. 2014;10(4):637-42.

8. Destors M, Tamisier R, Baguet JP, Levy P, Pepin JL. [Cardiovascular morbidity associated with obstructive sleep apnea syndrome]. Revue des maladies respiratoires. 2014;31(4):375-85.

9. Redline S, Yenokyan G, Gottlieb DJ, Shahar E, O'Connor GT, Resnick HE, et al. Obstructive sleep apnea-hypopnea and incident stroke: the sleep heart health study. American journal of respiratory and critical care medicine. 2010;182(2):269-77.

10. Ryan S, Taylor CT, McNicholas WT. Systemic inflammation: a key factor in the pathogenesis of cardiovascular complications in obstructive sleep apnoea syndrome? Postgraduate medical journal. 2009;85(1010):693-8.

11. Zamarron C, Valdes Cuadrado L, Alvarez-Sala R. Pathophysiologic mechanisms of cardiovascular disease in obstructive sleep apnea syndrome. Pulmonary medicine. 2013;2013:521087.

12. Castro-Anon O, Perez de Llano LA, De la Fuente Sanchez S, Golpe R, Mendez Marote L, Castro-Castro J, et al. Obesityhypoventilation syndrome: increased risk of death over sleep apnea syndrome. PloS one. 2015;10(2):e0117808.

13. Ucar ZZ, Cirak AK, Olcay S, Uysal H, Demir AU, Ozacar R. Association of duration of sleep and cardiovascular and metabolic comorbidities in sleep apnea syndrome. Sleep disorders. 2012;2012:316232.

14. Bath PM, Butterworth RJ. Platelet size: measurement, physiology and vascular disease. Blood coagulation \& fibrinolysis : an international journal in haemostasis and thrombosis. 1996;7(2):157-61.
15. Thompson CB, Jakubowski JA. The pathophysiology and clinical relevance of platelet heterogeneity. Blood. 1988;72(1):1-8.

16. Gibson PH, Cuthbertson BH, Croal BL, Rae D, El-Shafei H, Gibson $\mathrm{G}$, et al. Usefulness of neutrophil/lymphocyte ratio as predictor of new-onset atrial fibrillation after coronary artery bypass grafting. The American journal of cardiology. 2010;105(2):186-91.

17. Nilsson L, Wieringa WG, Pundziute G, Gjerde M, Engvall J, Swahn E, et al. Neutrophil/Lymphocyte ratio is associated with non-calcified plaque burden in patients with coronary artery disease. PloS one. 2014;9(9):e108183.

18. Zahorec R. Ratio of neutrophil to lymphocyte counts--rapid and simple parameter of systemic inflammation and stress in critically ill. Bratislavske lekarske listy. 2001;102(1):5-14.

19. Azab B, Shah N, Akerman M, McGinn JT, Jr. Value of platelet/ lymphocyte ratio as a predictor of all-cause mortality after nonST-elevation myocardial infarction. Journal of thrombosis and thrombolysis. 2012;34(3):326-34.

20. Gary T, Pichler M, Belaj K, Hafner F, Gerger A, Froehlich H, et al. Platelet-to-lymphocyte ratio: a novel marker for critical limb ischemia in peripheral arterial occlusive disease patients. PloS one. 2013;8(7):e67688.

21. Koseoglu HI, Altunkas F, Kanbay A, Doruk S, Etikan I, Demir O. Platelet-lymphocyte ratio is an independent predictor for cardiovascular disease in obstructive sleep apnea syndrome. Journal of thrombosis and thrombolysis. 2015;39(2):179-85.

22. Yenigun A, Karamanli H. Investigation of the relationship between neutrophil-to-lymphocyte ratio and obstructive sleep apnoea syndrome. The Journal of laryngology and otology. 2015;129(9):887-92.

23. Yasar Z, Buyuksirin M, Ucsular FD, Kargi A, Erdem F, Talay F, et al. Is an elevated neutrophil-to-lymphocyte ratio a predictor of metabolic syndrome in patients with chronic obstructive pulmonary disease? European review for medical and pharmacological sciences. 2015;19(6):956-62.

24. Christoffersson G, Vagesjo E, Pettersson US, Massena S, Nilsson EK, Broman JE, et al. Acute sleep deprivation in healthy young men: impact on population diversity and function of circulating neutrophils. Brain, behavior, and immunity. 2014;41:162-72.

25. Boudjeltia KZ, Faraut B, Stenuit P, Esposito MJ, Dyzma M, Brohee D, et al. Sleep restriction increases white blood cells, mainly neutrophil count, in young healthy men: a pilot study. Vascular health and risk management. 2008;4(6):1467-70.

26. Barcelo A, Pierola J, de la Pena M, Esquinas C, Fuster A, Sanchez-de-la-Torre $M$, et al. Free fatty acids and the metabolic syndrome in patients with obstructive sleep apnoea. The European respiratory journal. 2011;37(6):1418-23.

27. Xu H, Yi H, Guan J, Yin S. Effect of continuous positive airway pressure on lipid profile in patients with obstructive sleep apnea syndrome: a meta-analysis of randomized controlled trials. Atherosclerosis. 2014;234(2):446-53. 
28. Li J, Zhang Y, Wang J, Feng P, Chen R, Cao Y, et al. [Association between serum lipoprotein lipase level and dyslipidemia in patients with obstructive sleep apnea syndrome]. Zhonghua yi xue za zhi. 2014;94(6):403-7.

29. Chou YT, Chuang LP, Li HY, Fu JY, Lin SW, Yang CT, et al. Hyperlipidaemia in patients with sleep-related breathing disorders: prevalence \& risk factors. The Indian journal of medical research. 2010;131:121-5.

30. Parish JM, Adam T, Facchiano L. Relationship of metabolic syndrome and obstructive sleep apnea. Journal of clinical sleep medicine : JCSM : official publication of the American Academy of Sleep Medicine. 2007;3(5):467-72.

31. Li J, Thorne LN, Punjabi NM, Sun CK, Schwartz AR, Smith $\mathrm{PL}$, et al. Intermittent hypoxia induces hyperlipidemia in lean mice. Circulation research. 2005;97(7):698-706.

32. Gunbatar H, Sertogullarindan B, Ekin S, Akdag S, Arisoy A, Sayhan H. The correlation between red blood cell distribution width levels with the severity of obstructive sleep apnea and carotid intima media thickness. Medical science monitor: international medical journal of experimental and clinical research. 2014;20:2199-204.
33. Tsiara S, Elisaf M, Jagroop IA, Mikhailidis DP. Platelets as predictors of vascular risk: is there a practical index of platelet activity? Clinical and applied thrombosis/hemostasis : official journal of the International Academy of Clinical and Applied Thrombosis/Hemostasis. 2003;9(3):177-90.

34. Beyan C, Kaptan K, Ifran A. Platelet count, mean platelet volume, platelet distribution width, and plateletcrit do not correlate with optical platelet aggregation responses in healthy volunteers. Journal of thrombosis and thrombolysis. 2006;22(3):161-4.

35. Kurt OK, Yildiz N. The importance of laboratory parameters in patients with obstructive sleep apnea syndrome. Blood coagulation \& fibrinolysis: An international journal in haemostasis and thrombosis. 2013;24(4):371-4.

36. Vagdatli E, Gounari E, Lazaridou E, Katsibourlia E, Tsikopoulou F, Labrianou I. Platelet distribution width: a simple, practical and specific marker of activation of coagulation. Hippokratia. 2010;14(1):28-32. 
